\title{
Indoor Air Quality Assessment Based on Human Physiology - Part 1. New Criteria Proposal
}

\author{
M. V. Jokl
}

Human physiology research makes evident that the Weber-Fechner law applies not only to noise perception but also to the perception of other environmental components. Based on this fact, new decibel units for odor component representing indoor air quality in majority locations have been proposed: decicarbdiox dCd (for carbon dioxide $\mathrm{CO}_{2}$ ) and decitvoc dTv (for total volatile organic compound TVOC). Equations of these new units have been proved by application of a) experimental relationships between odor intensity (representing odor perception by the human body) and odor concentrations of $\mathrm{CO}_{2}$ and TVOC, b) individually measured $\mathrm{CO}_{2}$ and TVOC levels (concentrations) - from these new decibel units can be calculated and their values compared with decibel units of noise measured in the same locations. The undoubted benefit of using the decibel scale is that it gives much better approximation to human perception of odor intensity compared to the CO $\mathrm{O}_{2}$ and TVOC concentration scales.

Keywords: indoor air quality, odors, air changes estimation.

\section{Introduction: the "indoor quality" concept}

The quality of indoor air is affected by all components of the environment, the so-called constituents of the microclimate (see Fig. 1.1, Table 1.1) [27]. Existence of the individual components is obvious from: (1) the differential equation of the environment (only agents creating exposing flows in the human organism can be taken into account), (b) the stress theory according to Selye (each constituent is created only by those agents or complexes of agents creating one type of stress in the human body, see [27]).

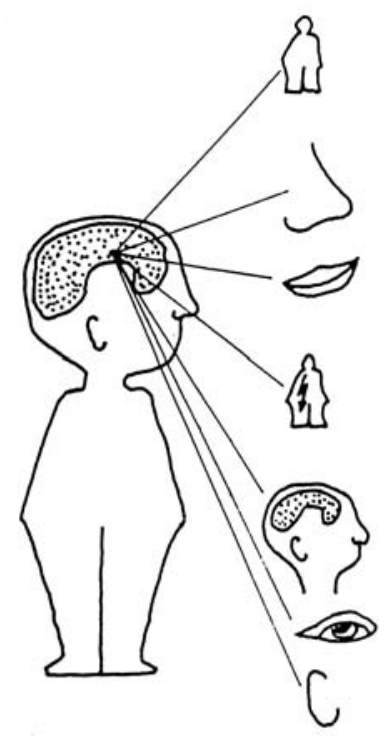

HYGRO-THERMAL CONSTITUENT

TOXIC CONSTITUENT

ODOUR CONSTITUENT

AEROSOL CONSTITUENT

MICROBIAL CONSTITUENT

IONIZING CONSTITUENT

ELECTRO-IONIC CONSTITUENT

ELECTROSTATIC CONSTITUENT

ELECTROMAGNETIC CONSTITUENT

PSYCHIC CONSTITUENT

LIGHT CONSTITUENT

ACOUSTIC CONSTITUENT

Fig. 1.1: Types of constituent

Air quality is thus dependent on its temperature and relative humidity, the concentrations of odors and toxic materials, the number of aerosols and microbes in the air, contamination by radioactive gases, static electricity and the numbers of negative and positive ions in the air.

The impact of each of these factors depends on the magnitude of the stimulus. Taking into account air quality only,
Table 1.1: Common environmental agents and corresponding microclimate types

\begin{tabular}{|c|c|c|c|}
\hline \multicolumn{2}{|r|}{ AGENTS } & \multicolumn{2}{|c|}{ MICROCLIMATE } \\
\hline MATERIAL & $\begin{array}{l}\text { TOXIC SOLIDS } \\
\text { SOLID AEROSOLS } \\
\text { MICRO-ORGANISMUS } \\
\text { TOXIC LIQUIDS } \\
\text { LIQUID AEROSOLS } \\
\text { TOXIC GASES } \\
\text { ODOURS } \\
\text { AIR (ITS MOVEMENT) } \\
\text { SPACE (ITS COLOURNESS) } \\
\text { MAN (AS AN OBJECT) } \\
\text { WATER VAPOURS }\end{array}$ & $\begin{array}{l}\text { AEROSOL } \\
\text { MICROBIAL } \\
\text { AEROSOL } \\
\text { TOXIC } \\
\text { ODOUR }\end{array}$ & 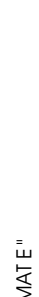 \\
\hline ENERGETIC & $\begin{array}{l}\text { HEAT CONVECTION } \\
\text { CONDUCTION } \\
\text { EVAPORATION } \\
\text { RESPIRATION } \\
\text { RADIATION } \\
\text { LIGHT } \\
\text { UV RADIATION } \\
\text { LASER RADIATION } \\
\text { MICROWAVE RADIATION } \\
\text { (RADAR) } \\
\text { IONIZING RADIATION } \\
\text { IONS IN SURROUNDING AIR } \\
\text { STATIC ELECTRICITY } \\
\text { SOUND } \\
\text { FORCE FIELD } \\
\text { (GRAVITATION) } \\
\text { VIBRATION }\end{array}$ & $\begin{array}{l}\text { HYGRO-THERMAL } \\
\text { ELECTRO-DYNAMIC } \\
\text { ELECTRO-IONIC } \\
\text { ELECTROSTATIC } \\
\text { ACOUSTIC }\end{array}$ & 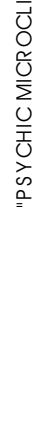 \\
\hline
\end{tabular}

i.e. the chemical components of indoor air, pleasant or unpleasant odors dominate the perception of the environment by the occupant, if there are no significant indoor sources. That is-why odors have become the criteria for assessing overall air quality [39], [41].

However, we always have to remember that it is solely the odor microclimate that we are evaluating and not the overall indoor air quality. This means that, if a significant source is present, e.g. water vapour or carbon monoxide, the hygrothermal or the toxic constituent has to be evaluated according to its own criteria (e.g. acceptable relative humidity of the air or acceptable carbon monoxide concentration).

Simultaneously, the increasing requirements for indoor air quality in buildings need more exact criteria in order to ascertain the real condition of the environment and to allow 
better optimization of its level (see [29], [30]), to remove "sick building" symptoms, i.e. to get the real comfort within a building.

Human physiology research makes evident that the Weber-Fechner law applies not only to noise perception but also to the perception of other environmental components. According to this law human body response $(R)$ is proportionate to the logarithm of the stimulus $(S$; k is a constant):

$$
R=\mathrm{k} \log S \text {. }
$$

Applied to acoustic component of the environment

$$
L_{P}=S P L=20 \log \frac{P}{P_{0}}[\mathrm{~dB}],
$$

where $L_{P}=S P L=$ sound pressure level $[\mathrm{dB}) ; P=$ acoustic pressure (when measuring the RMS value, i.e. the square root of the arithmetic average of a set of squared instantaneous values); $P_{0}=$ acoustic pressure at the threshold of hearing (for air $\mathrm{P}_{0}=20 \mu \mathrm{Pa}$ ).

Analogical relationship could be supposed for odor component of environment [27] which determines the necessary indoor air exchange (by which unpleasant odors should be removed, the toxic gases removal by ventilation usually highly exceeds ordinary requirements and must be solved separately):

$$
L_{\text {odor }}=\mathrm{k}_{\text {odor }} \log \left(\rho / \rho_{0}\right)[\mathrm{dB}],
$$

where $L_{\text {odor }}$ represents the odor concentration level in $\mathrm{dB}$ (the value representing the human response, i.e. odor perception $[\mathrm{dB}]), \rho$ represents the odor concentration in a building interior $\left[\mathrm{g} \cdot \mathrm{m}^{-3}\right],[\mathrm{ppm}], \rho_{0}$ represents the odor concentration threshold value $\left[\mathrm{g} \cdot \mathrm{m}^{-3}\right]$, $[\mathrm{ppm}]$.

The psycho-physical scale by Jaglou (the scale of perceived odors) could be applied to odor concentration levels [18]. In relationship to the percentage of dissatisfied (PD) its experimentally formed course is presented in Fig. 1.2.

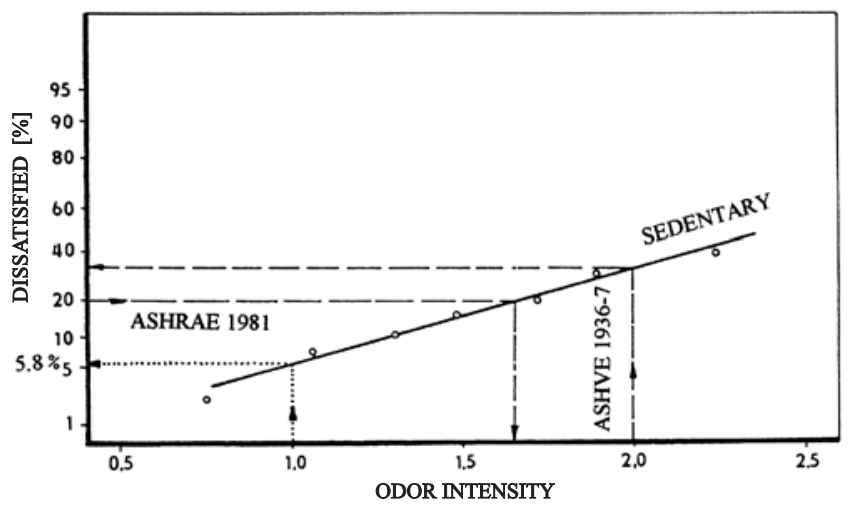

Fig. 1.2: The relationship between odor intensity (Yaglou's psycho-physical scale) and the percentage of dissatisfied sedentary subjects during light activity (smoking not permitted) [18]

It is a logarithmic function (see equation (1)) that proves the logarithmic form of equation (3).

The odor indoor air quality, decisive for air exchange, is dominantly determined by two odor substances: carbon dioxide $\mathrm{CO}_{2}$, which cannot be neglected in rooms occupied by a higher number of people (it is produced by respiration) and the complex of volatile organic compounds (VOC) produced by the majority of upholstery and building materials.
The following equations could be written for $\mathrm{CO}_{2}$ and TVOC:

$L_{\text {odor } \mathrm{CO}_{2}}=\mathrm{k}_{\text {odor } \mathrm{CO}_{2}} \log \left(\rho_{\mathrm{CO}_{2}} / \rho_{0 \mathrm{CO}_{2}}\right)[\mathrm{dB} \mathrm{CO} 2]$,

$L_{\text {odor TVOC }}=\mathrm{k}_{\text {odor TVOC }} \log \left(\rho_{\text {TVOC }} / \rho_{\text {0 TVOC }}\right)$ [dB TVOC]

where $\rho_{\mathrm{CO}_{2}}$ and $\rho_{\mathrm{TVOC}}$ represent the concentrations of $\mathrm{CO}_{2}$ and TVOC.

Even though these equations $(4,5)$ look very promising from the physiological point of view, they must be experimentally proved. Furthermore, at least two points are necessary for each equation: (1) minimum threshold value, i.e. the weakest odor that can be detected (odor tresholds are statistically determined points usually defined as the point at which $50 \%$ of a given population will perceive on odor" [24]), (2) any second point can be chosen. We prefer the maximum threshold (limit) value, i.e. the beginning of the toxic range.

The weakest odor that the smell organ of a healthy human can register has an intensity of 1, according to the Yaglou psycho-physical scale [18], and corresponds approximately to a percentage dissatisfaction (PD) of $5.8 \%$ (see Fig. 1.2). If we respect the similarity theory (see [21]), according to which analogous phenomena are governed by the same laws (e.g., concerning the perception of noise, odor etc. with intensity as a logarithmic function), then the corresponding minimal value for thermal comfort, as defined by Fanger [16], is 5 which is not too dissimilar from 5.8 for Yaglou's odor value, taking into account the demanding nature of the experimental procedure.

There is a good collection of experimental values in literature, therefore it has not been necessary to rely on our own measurements; even complete curves (see for example Fig. 1.2) are available.

\section{Carbon dioxide}

For a long time, the odor constituent has been evaluated on the basis of $\mathrm{CO}_{2}$ concentration and its limit value of $1000 \mathrm{ppm}$, introduced by von Pettenkoffer (see [42]), was used to determine the minimum amount of fresh air (25 $\mathrm{m}^{3} \cdot \mathrm{h}^{-1}$ per person). $\mathrm{CO}_{2}$ is the most important biologically active agent whose production is proportional to human metabolic ratio [24]. In practice, monitoring $\mathrm{CO}_{2}$ levels for the purpose of controlling fresh air supply has proved satisfactory for lecture theatres, halls, cinemas, theatres and similar spaces where the load imposed by occupants can vary rapidly.

In order to prove the equation (4), another experimental relationship besides the experimental relationship presented in Fig. 1.2 must be available: namely, the relationship between $\mathrm{PD}$ and $\mathrm{CO}_{2}$ concentration. This is presented in Fig. 1.3.

Now we are able to shape the equation (4). The first point, the minimum threshold value for $\mathrm{CO}_{2}$ can be taken as $5.8 \%$ dissatisfaction (Yaglou psycho-physical scale: 1), which is 485 ppm, i.e. $875 \mathrm{mg} \cdot \mathrm{m}^{-3}$ Figs. 1.2 and 1.3 [15]. The second point used was the short-term exposure limit, which is the beginning of the toxic range, i.e. $15000 \mathrm{ppm}$. This is based on [22] from the Health and Safety Executive (HSE) Occupational Exposure Limits of Great Britain. 


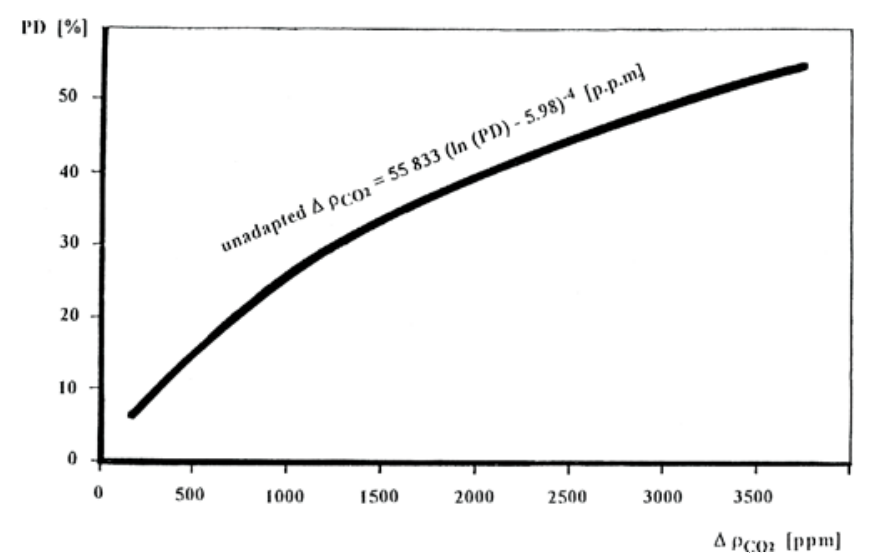

Fig. 1.3: The percentage of dissatisfied sedentary subjects as a function of the carbon dioxide concentration above outdoors
So we are able to formulate the equation for odor level:

$L_{\text {odor } \mathrm{CO}_{2}}=90 \log \frac{\rho_{i \mathrm{CO}_{2}}[\mathrm{ppm}]}{485}$ [decicarbdiox, dCd]

$\left(\mathrm{k}_{\text {odor } \mathrm{CO}_{2}} \log (15000 / 485)=135 \Rightarrow \mathrm{k}_{\text {odor } \mathrm{CO}_{2}}=90\right)$

or

$L_{\text {odor } \mathrm{CO}_{2}}=90 \log \frac{\rho_{i \mathrm{CO}_{2}}\left[\mathrm{mg} \cdot \mathrm{m}^{-3}\right]}{875}[$ decicarbdiox, dCd $]$ (6a)

where decicarbdiox, $\mathrm{dCd}$, is a new decibel unit for odor level (decibel carbon dioxide) caused by $\mathrm{CO}_{2}$ production by humans, $\rho_{i \mathrm{CO}_{2}}$ is indoor air concentration, $\mathrm{k}_{\text {odor } \mathrm{CO}_{2}}$ is constant.

Besides experimental functions already applied to equation (4), a lot of individually measured $\mathrm{CO}_{2}$ levels from various locations (Tables 1.2 and 1.3, Fig. 1.4) are available for the verification of the equation (4).

New decibel units dCd can be calculated from the measured $\mathrm{CO}_{2}$ concentrations and their values can be compared

Table 1.2: Measured $\mathrm{CO}_{2}$ levels in various locations [23]

\begin{tabular}{|c|c|c|c|c|c|}
\hline \multirow[t]{2}{*}{ Sample } & \multicolumn{2}{|c|}{ Mean, dCd / ppm } & \multicolumn{2}{|c|}{ Range, dCd / ppm } & \multirow[t]{2}{*}{ Study } \\
\hline & $S$ & $N S$ & $S$ & $N S$ & \\
\hline \multicolumn{6}{|l|}{ Public places } \\
\hline 39 schools (NS) & - & $\begin{array}{c}28 \mathrm{dCd} \\
990 \mathrm{ppm}\end{array}$ & $\begin{array}{l}- \\
-\end{array}$ & $\begin{array}{c}-5 \text { to } 68 \\
425-2800\end{array}$ & Smedje et al 1994 \\
\hline 10 schools (NS) & - & $\begin{array}{c}38 \\
1300\end{array}$ & $\begin{array}{l}- \\
-\end{array}$ & $\begin{array}{l}- \\
-\end{array}$ & Thorstensen et al 1990 \\
\hline 14 town halls (S) & $\begin{array}{c}20 \\
800\end{array}$ & $\begin{array}{l}- \\
-\end{array}$ & $\begin{array}{c}1 \text { to } 38 \\
500-1300\end{array}$ & $\begin{array}{l}- \\
-\end{array}$ & Skov, Valbjorn 1987 \\
\hline 5 office buildings (S) & - & - & $\begin{array}{l}<26 \\
<950\end{array}$ & $\begin{array}{l}- \\
-\end{array}$ & Palonen, Sepanen, 1990 \\
\hline 4 office buildings (S) & $\begin{array}{c}20 \\
800\end{array}$ & - & $\begin{array}{c}-8 \text { to } 38 \\
400-1300\end{array}$ & $\begin{array}{l}- \\
-\end{array}$ & Loewenstein 1989 \\
\hline 26 office buildings (S) & $\begin{array}{c}11 \\
639.4\end{array}$ & - & $\begin{array}{l}-13 \text { to } 52 \\
350-1850\end{array}$ & $\begin{array}{l}- \\
-\end{array}$ & Reynolds et al 1990 \\
\hline 10 kindergarten & - & $\begin{array}{c}27 \\
962.7\end{array}$ & $\begin{array}{l}- \\
-\end{array}$ & $\begin{array}{c}25 \text { to } 66 \\
915-2590\end{array}$ & Piade et al 1988 \\
\hline 1 office building (S) & $\begin{array}{l}-6 \\
420\end{array}$ & - & - & - & Jaakola et al 1990 \\
\hline $\begin{array}{l}10 \text { offices } \\
(5 \mathrm{~S}, 5 \mathrm{NS} \text { assumed })\end{array}$ & $\begin{array}{c}8 \\
590\end{array}$ & $\begin{array}{c}4 \\
533\end{array}$ & $\begin{array}{l}- \\
-\end{array}$ & $\begin{array}{l}- \\
-\end{array}$ & Proctor et al 1989 \\
\hline 1 office & - & - & $\begin{array}{l}8 \text { to } 13 \\
600-675\end{array}$ & - & Berglund et al 1982 \\
\hline 1 library & - & $\begin{array}{c}16 \\
731.5\end{array}$ & $\begin{array}{l}- \\
-\end{array}$ & $\begin{array}{l}- \\
-\end{array}$ & Berglund et al 1988 \\
\hline 9 office buildings (S) & $\begin{array}{c}15 \\
710.6\end{array}$ & $\begin{array}{l}- \\
-\end{array}$ & $\begin{array}{l}- \\
-\end{array}$ & $\begin{array}{l}- \\
-\end{array}$ & Jones 1980 \\
\hline \multicolumn{6}{|l|}{ Homes $^{\text {a) }}$} \\
\hline $\begin{array}{l}10 \text { homes and } \\
\text { apartments }\end{array}$ & \multicolumn{2}{|c|}{$\begin{array}{c}14 \\
692\end{array}$} & \multicolumn{2}{|c|}{$\begin{array}{c}-1 \text { to } 40 \\
470-1360\end{array}$} & van der Wal et al 1990 \\
\hline
\end{tabular}


Table 1.2: Measured $\mathrm{CO}_{2}$ levels in various locations [23] (continue)

\begin{tabular}{|c|c|c|c|c|c|}
\hline \multirow[t]{2}{*}{ Sample } & \multicolumn{2}{|c|}{ Mean, dCd / ppm } & \multicolumn{2}{|c|}{ Range, dCd / ppm } & \multirow[t]{2}{*}{ Study } \\
\hline & $S$ & $N S$ & $S$ & $N S$ & \\
\hline 18 homes & \multicolumn{2}{|c|}{$\begin{array}{c}6 \\
570\end{array}$} & \multicolumn{2}{|c|}{$\begin{array}{l}-13 \text { to } 24 \\
350-900\end{array}$} & Keskinen, Graeffe 1989 \\
\hline 57 homes & \multicolumn{2}{|c|}{$\begin{array}{c}16 \\
730.5\end{array}$} & \multicolumn{2}{|c|}{$\begin{array}{l}- \\
-\end{array}$} & $\begin{array}{l}\text { van Dangen, } \\
\text { van der Wal } 1990\end{array}$ \\
\hline living room b.r. & \multicolumn{2}{|c|}{$\begin{array}{c}29 \\
1024\end{array}$} & \multicolumn{2}{|c|}{$\begin{array}{l}- \\
-\end{array}$} & Op't Veld, Slijpen 1993 \\
\hline living room a.r. & \multicolumn{2}{|c|}{$\begin{array}{c}23 \\
882\end{array}$} & \multicolumn{2}{|c|}{$\begin{array}{l}- \\
-\end{array}$} & Op't Veld, Slijpen 1993 \\
\hline kitchen b.r. & \multicolumn{2}{|c|}{$\begin{array}{c}29 \\
1013\end{array}$} & \multicolumn{2}{|c|}{$\begin{array}{l}- \\
-\end{array}$} & Op't Veld, Slijpen 1993 \\
\hline kitchen a.r. & \multicolumn{2}{|c|}{$\begin{array}{c}21 \\
836\end{array}$} & \multicolumn{2}{|c|}{$\begin{array}{l}- \\
-\end{array}$} & Op't Veld, Slijpen 1993 \\
\hline bedroom b.r. & \multicolumn{2}{|c|}{$\begin{array}{c}25 \\
927\end{array}$} & \multicolumn{2}{|c|}{$\begin{array}{l}- \\
-\end{array}$} & Op't Veld, Slijpen 1993 \\
\hline bedroom a.r. & \multicolumn{2}{|c|}{$\begin{array}{c}13 \\
672\end{array}$} & \multicolumn{2}{|c|}{$\begin{array}{l}- \\
-\end{array}$} & Op't Veld, Slijpen 1993 \\
\hline
\end{tabular}

$S$ - smoking, NS - nonsmoking, a.r. - after renovation, b.r. - before renovation, negative values of dCd - measuring methods allow estimating of values below the detection threshold, ${ }^{\text {al }}$ no distiction made between smoking/non-smoking.

Table 1.3: Measured indoor quality parameters before and after renovation (mean values and standard deviations, $n=16$ ) [38]

\begin{tabular}{|c|c|c|c|c|c|c|c|c|}
\hline & & \multicolumn{3}{|c|}{ Before renovation } & \multicolumn{3}{|c|}{ After renovation } & \multirow{2}{*}{$\begin{array}{c}\text { WHO } 1987 \\
\text { guideline } \\
\text { values }\end{array}$} \\
\hline & & living room & kitchen & bedrooms & living room & kitchen & bedrooms & \\
\hline$(\mathrm{dCd})$ & mean & 29 & 29 & 25 & 23 & 21 & 13 & 35 \\
\hline $\mathrm{CO}_{2}$ & mean & 1024 & 1013 & 927 & 882 & 836 & 672 & 1200 \\
\hline (ppm) & std & 184 & 277 & 193 & 160 & 122 & 148 & \\
\hline $\mathrm{CO}$ & mean & 3.9 & 4.3 & 4.2 & 2.2 & 2.0 & 1.4 & $10(8 \mathrm{~h})$ \\
\hline$\left(\mathrm{mg} \cdot \mathrm{m}^{-3}\right)$ & std & 0.4 & 0.2 & 1.6 & 1.0 & 0.5 & 0.5 & \\
\hline $\mathrm{CH}_{2} \mathrm{O}^{*}$ & mean & 665 & 577 & 530 & 405 & 357 & 231 & $120(0.5 \mathrm{~h})$ \\
\hline$\left(\mu \mathrm{g} \cdot \mathrm{m}^{-3}\right)$ & std & 214 & 51 & 234 & 167 & 153 & 188 & \\
\hline TVOC $\left(\right.$ ref $\left.\mathrm{CH}_{4}\right)$ & mean & - & - & - & 4.5 & 4.1 & 2.9 & - \\
\hline$\left(\mathrm{mg} \cdot \mathrm{m}^{-3}\right)$ & std & - & - & - & 1.0 & 1.0 & 1.0 & \\
\hline $\mathrm{NO}_{2}$ & mean & 84 & 160 & 30 & 30 & 34 & 16 & 150 \\
\hline$\left(\mu \mathrm{g} \cdot \mathrm{m}^{-3}\right)$ & std & 40 & 127 & 9 & 16 & 14 & 3 & $(24 \mathrm{~h})$ \\
\hline Resp.dust & mean & 30 & - & - & 30 & - & - & 70 \\
\hline$\left(\mu \mathrm{g} \cdot \mathrm{m}^{-3}\right)$ & std & 16 & - & - & 15 & - & - & (PM10 24 h) \\
\hline $\mathrm{RH}(\%)$ & mean & 42 & 41 & 57 & 45 & 44 & 45 & $(30-70) \%$ \\
\hline & std & 4 & 6 & 9 & 4 & 3 & 4 & \\
\hline
\end{tabular}

* including a.o. other aldehydes, $\mathrm{C}_{5} \mathrm{H}_{12}, \mathrm{C}_{6} \mathrm{H}_{14}$ 


\section{MEASURED VALUES}

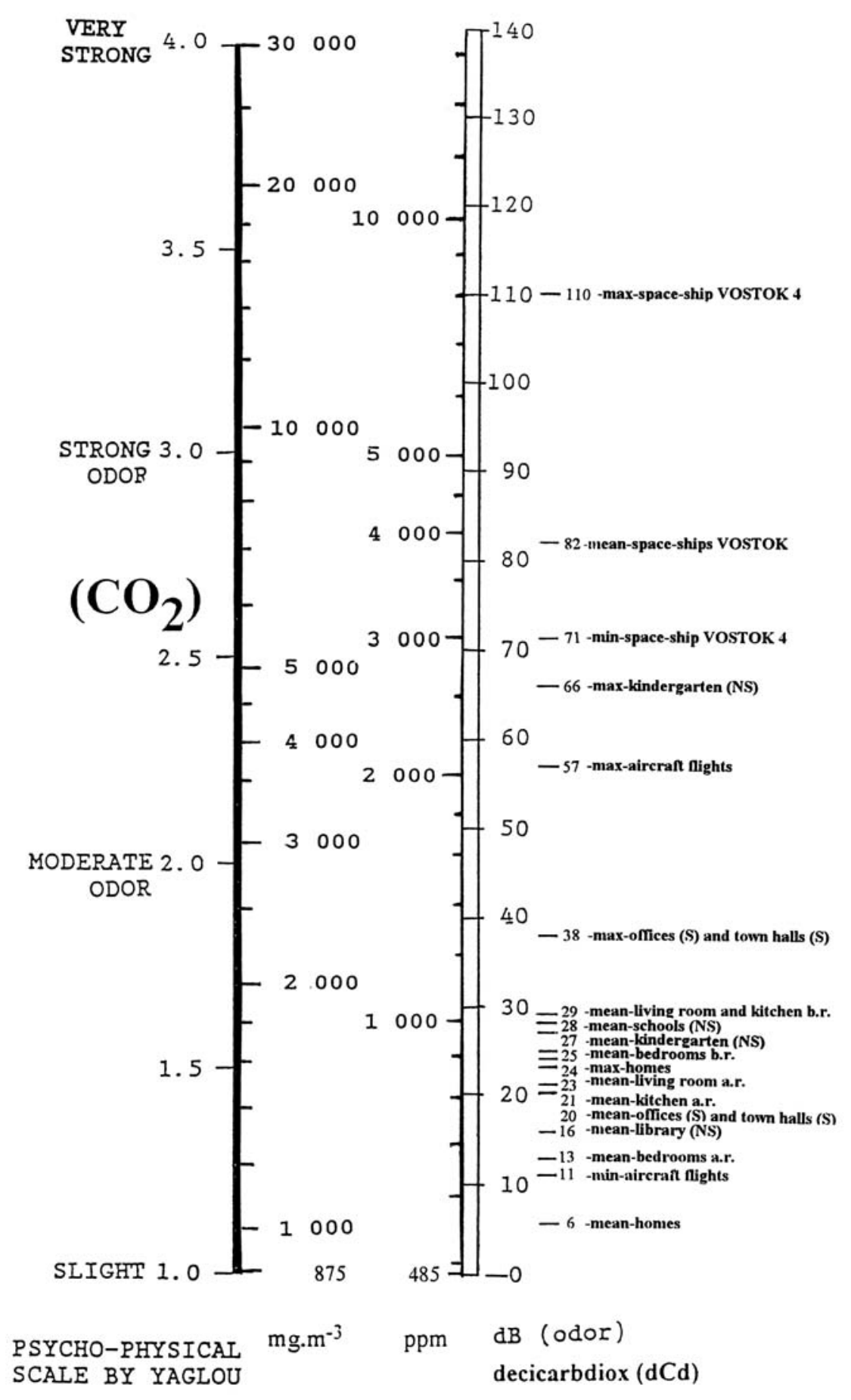

Fig. 1.4: The measured $\mathrm{CO}_{2}$ levels in various buildings (see Table 1.2); the psychophysical scale slightly modified by Fanger (1988), $S$ - smoking, $N S$ - nonsmoking, a.r. - after renovation, b.r. - before renovation

with decibel units for noise measured in the same locations

(Fig. 1.5). A perfect agreement is evident. 


\section{SOUND PRESSURE}

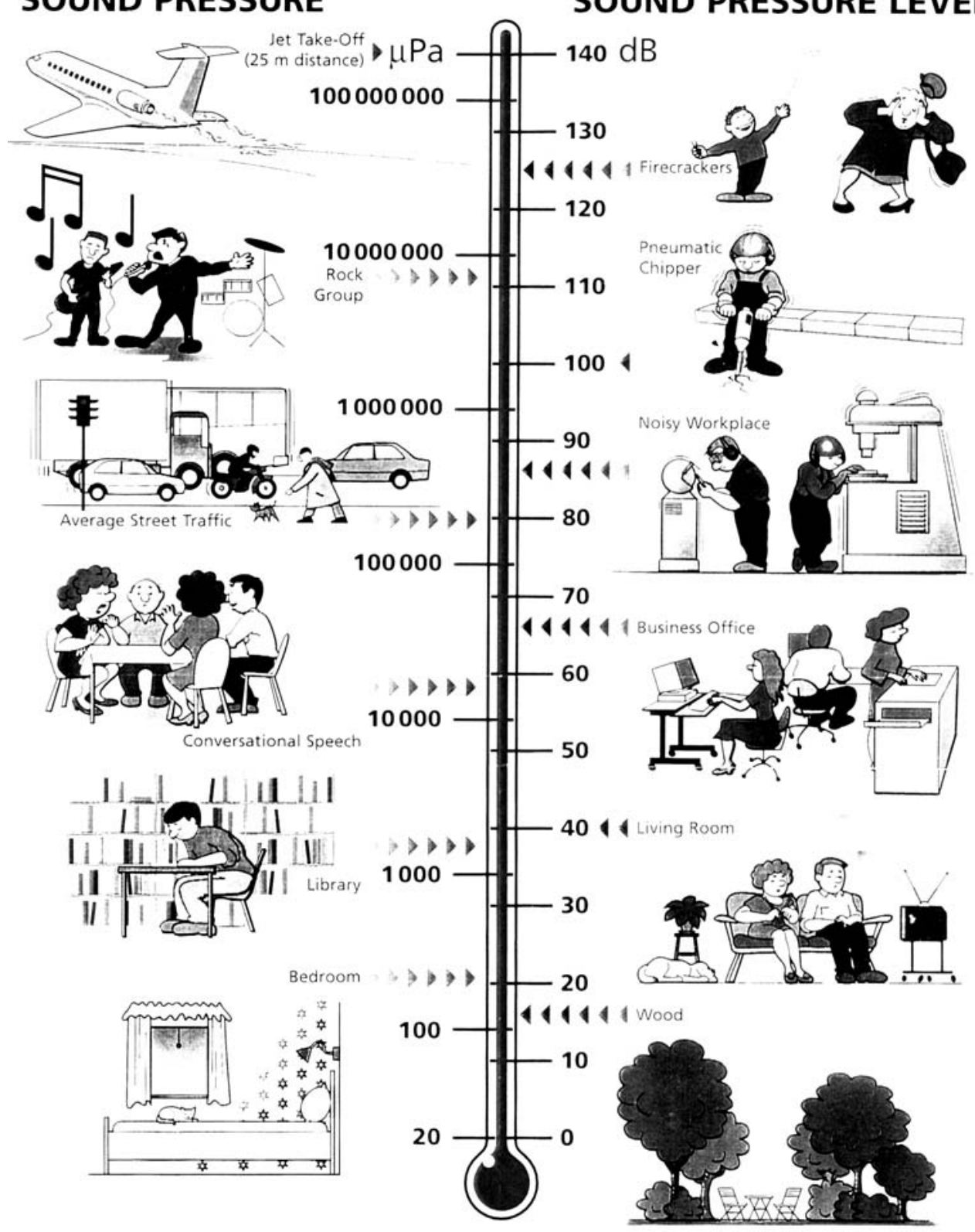

\section{Volatile organic compounds}

Although $\mathrm{CO}_{2}$ is a good indicator of the perceived air quality by sedentary persons, it is frequently also an unsuitable indicator: it does not represent further perceived sources of air contamination, such as building materials and fittings, especially carpets and other floor covering materials, producing VOC.

This was why Fanger [17] proposed a new system based on the units of the "olf" and "decipol". It was presented in a number of international periodicals and publications and in 1992 became the EU recommended method of evaluating indoor air quality (EUR $14449 \mathrm{EN}, 1992)$. It was not, however, accepted for the BSR/ASHRAE Standard 62-1989 R (1989). There are certain obvious problems with this system, as were analysed by Oseland [39], Jokl et al [28] and especially by Parine [41].
Fanger's system, as used in the EC standard, is based, rather than on $\mathrm{CO}_{2}$, on a new criterion: the total of all volatile organic compounds (TVOC) produced by humans and especially by building materials, furniture and other fittings. TVOC is also used for outside air quality as used for ventilation purposes, especially in areas with sources of contamination (chemical and other factories).

TVOC is defined by the World Health Organisation (WHO) as a set of agents (toluene, xylene, pinene, 2-(2etoxyetoxy), ethanol etc.) with a melting point below room temperature and a boiling point in the range $50-260{ }^{\circ} \mathrm{C}$. More detailed definitions also exist.

Humans sense TVOC by means of olfactory (smell) sensors (see [27]). Adaptation during the course of exposure is small. The response of the human organism to indoor TVOC has been classified as acute sensing of the environment, acute 
or sub-acute inflammation of the skin or mucous membranes, or a sub-acute and mild stress reaction [15].

In order to prove the equation (5), besides the experimental relationship presented in Fig. 1.2, another experimental relationship must be available: namely, the relationship between PD and TVOC concentrations. It is presented in Fig. 1.6.

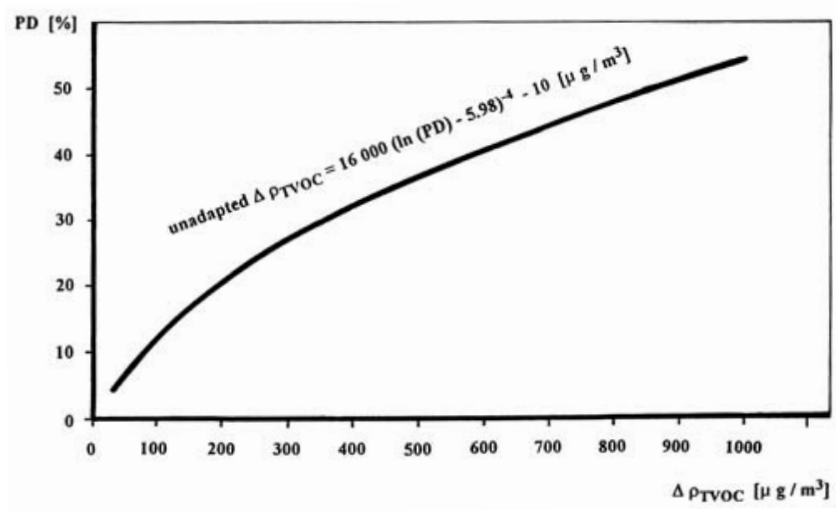

Fig. 1.6: The percentage of dissatisfied sedentary subjects as a function of the total volatile organic compound concentration (TVOC) above outdoors

Now we are able to shape the equation (5).

The first point, the minimum threshold value for TVOC, can be taken as $5.8 \%$ dissatisfaction (Yaglou psychophysical scale: 1) which is $50 \mu \mathrm{g} \cdot \mathrm{m}^{-3}$, see Fig. 1.6 (adapted from Fig. 1.2 in EUR $14449 \mathrm{EN}$, see [30]).

The second point used was the short-term exposure limit, which is the beginning of the toxic range, i.e. $25000 \mu \mathrm{g} \mathrm{m}^{-3}$, which has been estimated by Molhave [36].

So we are able to formulate the equation for odor level:

$$
\begin{aligned}
& L_{\text {odor TVOC }}=50 \log \frac{\rho_{i \text { TVOC }}}{50} \text { [decitvox, dTV] } \\
& \left(\mathrm{k}_{\text {odor TVOC }} \log (25000 / 50)=135 \Rightarrow \mathrm{k}_{\text {odor TVOC }}=50\right)
\end{aligned}
$$

where decitvoc, $\mathrm{dTv}$, is a new decibel unit for odor level caused by TVOC release from building materials and other sources (decibel TVOC), $\mathrm{k}_{\text {odor TVOC }}$ is a constant.

Besides experimental functions already applied to equation (5), a lot of individually measured TVOC levels from various locations (Tables 1.3 and 1.4, Fig. 1.7) are available for the verification of the equation (5).

New decibel units $\mathrm{dTv}$ can be calculated from the measured TVOC concentrations and their values can be compared with decibel units for noise measured in the same locations (Fig. 1.5). A perfect agreement is evident.

\section{Conclusions}

1. The undoubted benefit of using the decibel scale is that it gives a much better approximation to human preception of odor intensity compared to the $\mathrm{CO}_{2}$ and TVOC concentration scales. This is because the human olfactory organ (see [27]) reacts to a logarithmic change in level

\begin{tabular}{|c|c|c|c|c|c|c|c|}
\hline \multirow[t]{2}{*}{ Sample } & \multicolumn{3}{|c|}{ TVOC $\left[\mu \mathrm{g} \cdot \mathrm{m}^{-3}\right]$} & \multicolumn{3}{|c|}{ Odor level [dTv] } & \multirow[t]{2}{*}{ Study } \\
\hline & $\min$ & mean & $\max$ & $\min$ & mean & $\max$ & \\
\hline \multicolumn{7}{|l|}{ Living rooms and bedrooms } & \\
\hline old houses & 130 & 200 & 240 & 21 & 30 & 34 & \multirow{2}{*}{$\begin{array}{c}\text { Brown, Crump } \\
1993\end{array}$} \\
\hline new houses & 330 & 460 & 580 & 41 & 48 & 53 & \\
\hline non-asthmatics & 72 & 320 & 1600 & 8 & 40 & 75 & \multirow{2}{*}{$\begin{array}{c}\text { Nordbäck et al } \\
1993\end{array}$} \\
\hline asthmatics & 67 & 540 & 8300 & 6 & 52 & 111 & \\
\hline \multicolumn{7}{|l|}{ Office buildings } & \\
\hline \multicolumn{7}{|l|}{ a) without SBS } & \\
\hline during working hours & 43 & 51 & 61 & $-3^{*}$ & 0 & 4 & \multirow[t]{3}{*}{ Ekberg 1993} \\
\hline during night-time & 37 & 44 & 49 & $-6^{*}$ & $-3 *$ & 0 & \\
\hline during weekend & 37 & - & - & $-6^{*}$ & - & - & \\
\hline \multicolumn{8}{|l|}{ b) with SBS } \\
\hline (liquid process photo copiers) & - & 5000 & 90000 & - & 100 & 163 & Broder et al 1993 \\
\hline
\end{tabular}

Table 1.4: Measured TVOC values in various locations

SBS $=$ Sick Building Syndrome

* Measuring methods allow to estimate values under the detection threshold 


\section{MEASURED VALUES}

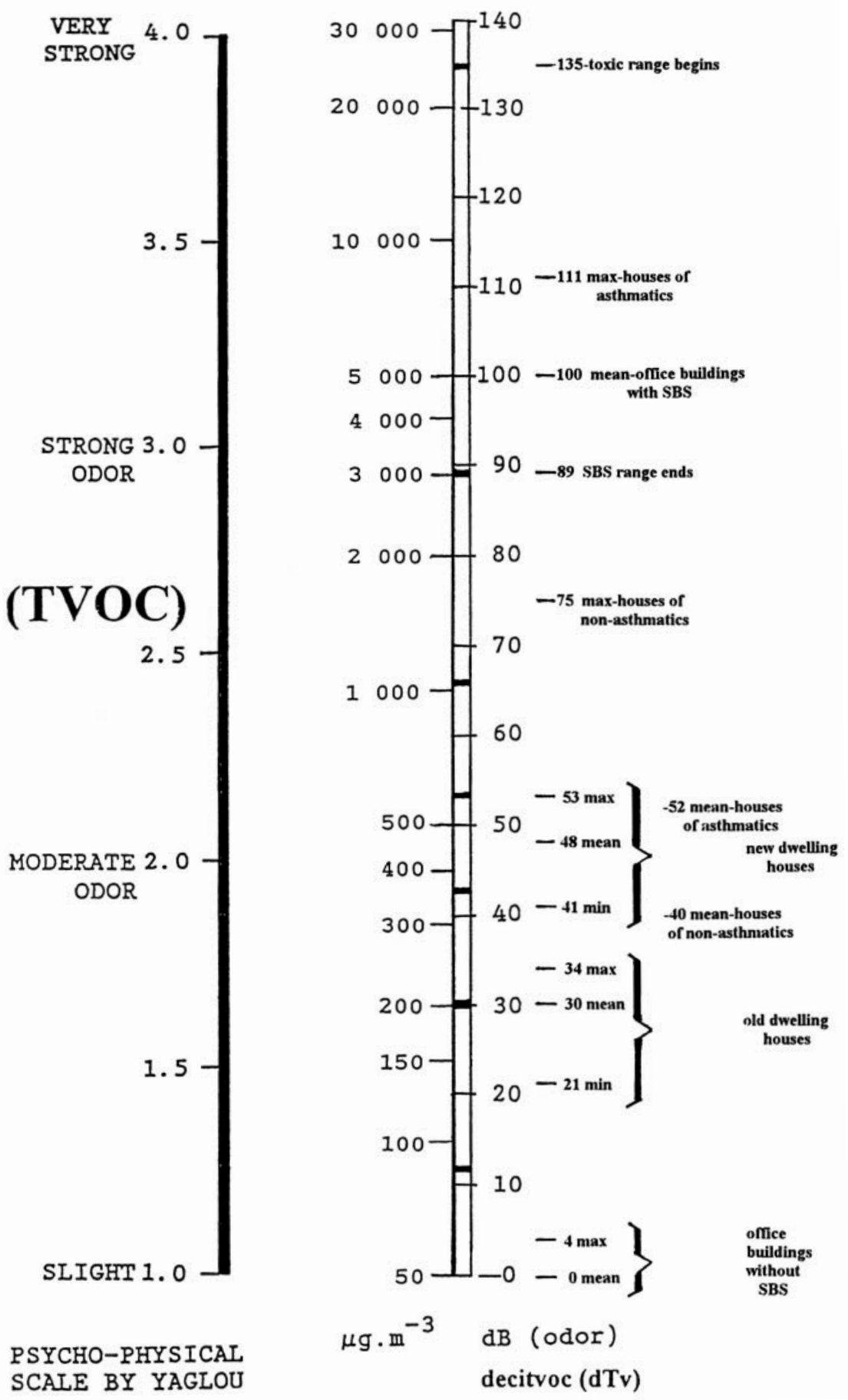

which corresponds to the decibel scale, where a change of $1 \mathrm{~dB}$ is approximately the same relative change everywhere on the scale.

2. The new decicarbdiox and decitvoc values also fit very well with the $\mathrm{dB}$ values for sound, e.g., the optimal odor value of $30 \mathrm{~dB}$ corresponds to the ISO Noise Rating
Acceptable Value NR 30 for libraries and private offices. They can therefore be compared to each other.

3. It is possible, by comparing dCd and dTv values, to estimate, which component $-\mathrm{CO}_{2}$ or TVOC - plays a more important role and hence which sources of contamination are more serious. 


\section{References}

See presented at the end of Part 3 (p. 44).

Prof. Ing. Miloslav V. Jokl, DrSc.

phone: +420224354432

email: miloslav.jokl@fsv.cvut.cz

Department of Engineering Equipment of Buildings

Czech Technical University in Prague

Faculty of Civil Engineering

16629 Prague 6, Czech Republic 